\title{
The cytokinetic and cytotoxic effects of ICRF-159 and ICRF-187 in vitro and ICRF-187 in human bone marrow in vivo
}

\author{
Richard H. Wheeler, ${ }^{1}$ Daniel J. Clauw, ${ }^{1}$ Ronald B. Natale ${ }^{1,2}$ and Raymond W. Ruddon ${ }^{3}$ \\ ${ }^{1}$ Department of Internal Medicine, Division of Hematology/Oncology, University of Michigan, Ann Arbor, \\ Michigan, U.S.A. \\ ${ }^{2}$ Veterans Administration Medical Center, Ann Arbor, Michigan, U.S.A. \\ ${ }^{3}$ Department of Pharmacology, University of Michigan, Ann Arbor, Michigan, U.S.A.
}

Key words: cytokinetic effects, cytotoxicity, ICRF-159/187

\section{Summary}

The cytotoxic and cytokinetic effects of ICRF-159 and its d-enantiomer ICRF-187 have been examined in vitro. The effects of both agents were identical. Cytotoxicity is dependent on both the drug concentration and the duration of drug exposure. Drug exposure for twice the cell cycle time is necessary for maximum effect. Cytotoxicity is also dependent upon the rate of cell proliferation. A rapidly growing cell population is more sensitive to brief drug exposure than a slowly growing population.

The cytokinetic effects were studied using flow cytometry, determination of $\left[{ }^{3} \mathrm{H}\right]$-thymidine incorporation and mitotic index. ICRF-159/187 appears to act only during the $\mathrm{G}_{2}$ phase of the cell cycle. There is no detectable delay in cell passage through the $\mathrm{G}_{1} / \mathrm{S}$ boundary or in transit through $\mathrm{S}$ phase. Inhibition of DNA synthesis occurs only after the $G_{2}$ block prevents subsequent entry of cells in $S$ phase. A fraction of the cells, depending upon drug concentration, undergo further DNA synthesis without cell division, resulting in a tetrapoid cell population.

The cytokinetic effects were determined in the bone marrow of patients receiving ICRF-187. All dose-rates produced $\mathrm{G}_{2} / \mathrm{M}$ accumulation in the marrow with depletion of $\mathrm{S}$ phase cells. One patient was given a single injection of $1.0 \mathrm{gm} / \mathrm{M}^{2} . \mathrm{G}_{2} / \mathrm{M}$ accumulation was observed $24 \mathrm{~h}$ after treatment, with recovery to a pretreatment DNA cycle distribution $24 \mathrm{~h}$ later.

These studies suggest that a continuous drug infusion, or intermittent infusions timed to allow the normal cell population to recover, may produce superior clinical activity with this agent. A Phase I study of such an intermittent schedule is indicated.

\section{Introduction}

ICRF-159 (razoxane), an EDTA derivative developed at the Imperial Cancer Research Fund, has shown antineoplastic activity in animal tumor models (1) as well as in clinical studies (2). A synergistic antineoplastic effect has been demonstrated in animal tumor models for combinations of ICRF-
159 plus irradiation, adriamycin, 5-fluorouracil, cisplatinum, cyclophosphamide, or hexamethylmelamine (3-6). Methotrexate resistant L5187Y cells are more sensitive to ICRF-159 than a methotrexate sensitive line (7).

Previous studies of the cellular effect of ICRF159 have produced somewhat conflicting results. Studies by Hellman and co-workers have suggested 
a site of action in the $G_{2}$ phase of the cell cycle with production of $\mathrm{G}_{2}$ arrest $(8-10)$. Other investigators have demonstrated inhibition of RNA, protein and DNA synthesis and have suggested that ICRF-159 acts as an alkylating agent (11). $\mathrm{G}_{2}$ arrest can be a non-specific effect of cell treatment with a number of antineoplastic agents with different mechanisms of action. Arrest in the $G_{2}$ phase has been demonstrated with alkylating agents, antitumor antibiotics, and protein synthesis inhibitors (12-14). Adriamycin has been shown to produce $\mathrm{G}_{2}$ arrest in vitro and cell recovery with subsequent progression through the cell cycle occurs only after brief exposure to low drug concentrations (15). Exposure to high drug concentrations or long exposure times result in irreversible arrest. Bleomycin, on the other hand, produces a $\mathrm{G}_{2}$ block that is reversible, and release of the block results in a synchronized cell population (16). This action of bleomycin has been demonstrated in human tumors in vivo (17) and has been successfully incorporated into clinical treatment regimens (18). Tobey has shown that various agents stop progression in different points in the $G_{2}$ phase and has suggested that the $\mathrm{G}_{2}$ phase may contain a surveillance mechanism for DNA damage (19). Demonstration of $\mathrm{G}_{2}$ arrest, therefore, does not automatically imply a $G_{2}$ phase specific site of action.

ICRF-159 is a racemic mixture. Because of poor water solubility, clinical trials were conducted with an oral formulation. However, recognition of variable bioavailability led to isolation and formulation of the more soluble d-enantomier ICRF-187 (20, 21). This parenteral agent has completed Phase I trials and is currently undergoing Phase II testing. This study was undertaken to further define the cytokinetic effects of ICRF-187, compare the in vitro effects of ICRF-159 and ICRF-187, determine the cytotoxic and cytokinetic effects of variation in drug concentration and exposure time, and assess the cytokinetic effect of ICRF-187 on the bone marrow of patients entered into Phase II trials utilizing continuous infusion, daily $\times 3$ and daily $\times 5$ treatment schedules.

\section{Materials and methods}

Burkitt lymphoma cells $\left(\mathrm{P}_{3} \mathrm{~J}\right)$ were maintained in continuous culture at $37^{\circ} \mathrm{C}$ in RPMI-1640 medium containing $10 \%$ fetal bovine serum, penicillin 100 $\mu \mathrm{g} / \mathrm{ml}$ and streptomycin $100 \mu \mathrm{g} / \mathrm{ml}$. Cells in the $\log$ phase of growth for $24 \mathrm{~h}$ were diluted with fresh culture medium to a concentration of $2.5-3.0 \times 10^{5}$ cells $/ \mathrm{ml}$ just prior to each experiment. At this initial cell concentration, untreated cultures remained in the $\log$ phase of growth for $36 \mathrm{~h}$ with a doubling time of $13-15 \mathrm{~h}$. After $72 \mathrm{~h}$ of growth, the cultures reached a growth plateau at a density of $2.2 \pm .2$ $\times 10^{6}$ cells $/ \mathrm{ml}$. Cell viability determined by erythrocin B dye exclusion, was in excess of $95 \%$ at the cell densities used in these experiments.

The small cell lung cancer line NCl-H69C, obtained from Dr. John Minna, The National Cancer Institute, was maintained in RPMI- 1640 containing $15 \%$ fetal calf serum with penicillin and streptomycin. Cells in the log phase of growth have a doubling time of 40-44 $\mathrm{h}$ and maintain a dye exclusion viability in excess of $85 \%$.

ICRF-159 (preservative-free, furnished by the National Cancer Institute) was dissolved in $0.1 \mathrm{~N}$ $\mathrm{HCl}$ immediately prior to use. ICRF-187, also obtained from the National Cancer Institute, was dis. solved in distilled water. Cytotoxicity was determined using a soft agar colony-forming assay. At indicated times aliquots were removed from replicate control and drug treated cultures, centrifuged then resuspended in medium containing $15 \%$ fetal bovine serum and $0.3 \%$ agar. One ml, containing $5 \times 10$ cells was pipetted over $1.0 \mathrm{ml}$ base layers containing $0.5 \%$ agar in $35 \mathrm{~mm}$ Petri dishes. The number of colonies per plate ( $>30$ cells/colony) were hand counted, using an inverted microscope, 5-7 days after plating. Percent survival was calculated as the number of colonies/plate for the drug treated cultures divided by the number of colonies/ plate for the controls. Cloning efficiency averaged $50 \pm 5 \%$ for the untreated $\mathrm{P}_{3} \mathrm{~J}$ cultures, and $10 \pm$ $2 \%$ for $\mathrm{H} 69 \mathrm{C}$. Each cloning assay was performed in triplicate. Each experiment was repeated at least once for both agents.

Thymidine incorporation was measured after the cultures were incubated with $\left[{ }^{3} \mathrm{H}\right]$-thymidine (Me- 
thyl- ${ }^{3} \mathrm{H}$-thymidine, $20 \mathrm{Ci} / \mathrm{mM}$, New England Nuclear, Boston, Mass), $0.5 \mu \mathrm{Ci} / \mathrm{ml}$, for $30 \mathrm{~min}$. The cells were immediately centrifuged and washed with 2 volumes of iced $0.9 \% \mathrm{NaCl}$. The nucleic acid was precipitated by addition of $4 \mathrm{ml}$ iced $5 \%$ perchloric acid, and the sample was centrifuged. After two further washes with iced perchloric acid, the pellet was resuspended in $1 \mathrm{ml} 5 \%$ perchloric acid and incubated at $90^{\circ} \mathrm{C}$ for $30 \mathrm{~min} .\left[{ }^{3} \mathrm{H}\right]$-thymidine content of the supernatant was determined by liquid scintillation counting in a Packard Tricarb Scintillation Counter and the DNA content was assayed by the diphenylamine method of Burton (22).

Mitotic index was determined by counting the number of mitoses/1000 cells using Wright-stained preparations. Cell counts were done with a Model F Coulter Counter.

Flow cytometry was performed using a Coulter TPS-1 Cell Sorter. Cells were prepared for fluorometric analysis of DNA content by incubation for $10 \mathrm{~min}$ in $0.05 \mathrm{mg} / \mathrm{ml}$ propidium iodine in $0.1 \%$ sodium citrate buffer at $0^{\circ} \mathrm{C}$ (23). $1.2-2.0 \times 10^{4}$ cells were analyzed per sample at a peak channel setting at $10^{4}$ cells.

\section{Patient samples}

Approval of this investigation was obtained from the University of Michigan Committee to Review Grants from Clinical Research and Investigation Involving Human Beings. Written informed consent was obtained from all participating subjects.

Bone marrow aspirates were obtained from the posterior iliac crest using a Jamshidi needle. Two to $3 \mathrm{ml}$ samples were withdrawn, anticoagulated with EDTA and divided into two aliquots for analysis by flow cytometry. The mononuclear cell fraction was separated by centrifugation in a Ficol/Hypaque gradient (Histopaque-1077, Sigma Chemical Co., St. Louis, Mo.), and stained with propidium iodide. The bone marrow sample cell count was determined on a Model F Coulter Counter after gradient separation of mononuclear cells.

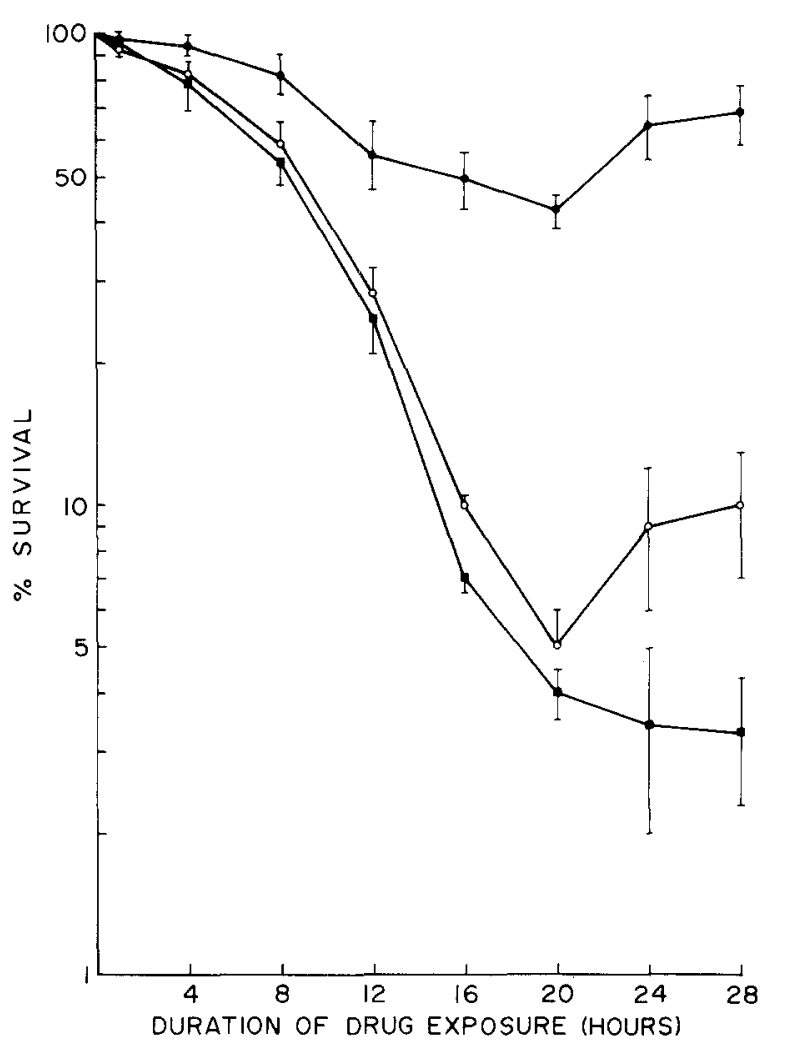

Fig. 1. The effects of drug concentration and exposure duration on ICRF-187 cytotoxicity. $\mathrm{P}_{3} \mathrm{~J}$ cells were exposed to ICRF-187 at the concentrations shown. At the indicated times aliquots were removed and cell kill was determined by the soft agar cloning assay.

, $1 \mu \mathrm{g} / \mathrm{ml} ; \bigcirc, 3 \mu \mathrm{g} / \mathrm{ml} ; \mathbf{E}, 10 \mu \mathrm{g} / \mathrm{ml}$.

\section{Results}

The experiments using $\mathrm{P}_{3} \mathrm{~J}$ cells shown in Figs. 1, 4, 8 and 9 were performed using ICRF-159 and ICRF-187. The cytotoxic and cytokinetic effects observed were identical for both agents. Dissolving ICRF-187 in $0.1 \mathrm{~N} \mathrm{HCl}$ did not alter the drug effect. Therefore the results obtained with either agent have been used interchangeably.

The effects of a timed exposure to $1 \mu \mathrm{g} / \mathrm{ml}, 3$ $\mu \mathrm{g} / \mathrm{ml}$ or $10 \mu \mathrm{g} / \mathrm{ml}$ of ICRF-187 is shown in Fig. 1 . A 28-h exposure to $10 \mu \mathrm{g} / \mathrm{ml}$ was required for maximum cytotoxicity. A drug concentration of 40 $\mu \mathrm{g} / \mathrm{ml}$ produced the same effect as is shown for 10 $\mu \mathrm{g} / \mathrm{ml}$. The cytotoxicity of 3 and $10 \mu \mathrm{g} / \mathrm{ml}$ was the same for exposure times of $12 \mathrm{~h}$ or less. Exposure to $3 \mu \mathrm{g} / \mathrm{ml}$ for $16 \mathrm{~h}$ or longer produced less cytotoxi- 


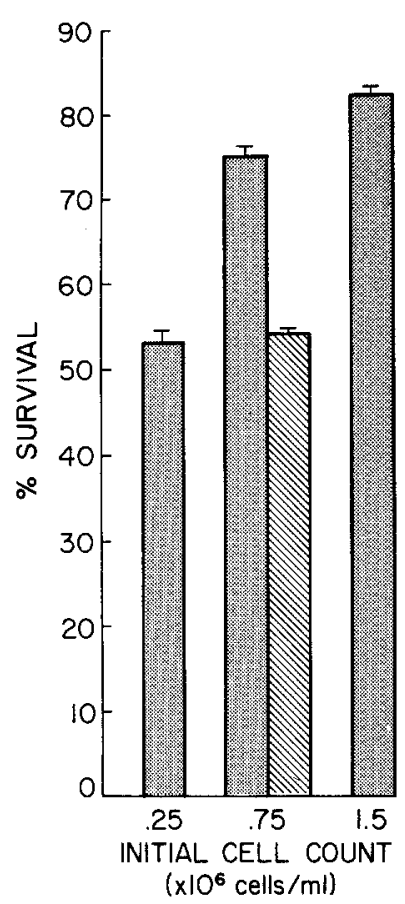

Fig. 2. The effect of cell proliferation rate on ICRF-159 cytotoxicity. $\mathrm{P}_{3} \mathrm{~J}$ cells at the initial cell densities shown, were incubated with 20 $\mu \mathrm{g} / \mathrm{ml}$ ICRF-159 for $14 \mathrm{~h}$ (stippled bars) or $21 \mathrm{~h}$ (hashed bar).

city than the $10 \mu \mathrm{g} / \mathrm{ml}$ drug concentration. By thirty hours, the cloning efficiency in cultures exposed to $3 \mu \mathrm{g} / \mathrm{ml}$ began to increase as the cells recovered from drug exposure, or possibly as cells resistant to this concentration continued to proliferate.

Some of the cytotoxicity difference between 10 $\mu \mathrm{g} / \mathrm{ml}$ and $1 \mu \mathrm{g} / \mathrm{ml}$ could result from drug breakdown with loss of effect at the lower concentration. Cells were therefore exposed to these two drug concentrations for a total of $24 \mathrm{~h}$, however, every $8 \mathrm{~h}$ the cultures were centrifuged and resuspended in fresh, drug-containing medium. Renewing the drug concentration every $8 \mathrm{~h}$ increased the cytotoxicity of 1 $\mu \mathrm{g} / \mathrm{ml}$ from $51 \pm 2 \%$ to $30 \pm 4 \%$ colony survival. This suggests that drug breakdown may have occurred during a single $24-\mathrm{h}$ exposure. The cytotoxicity produced by $10 \mu \mathrm{g} / \mathrm{ml}$ was not increased by drug replacement. Under both exposure conditions the cytotoxicity of $10 \mu \mathrm{g} / \mathrm{ml}$ was $5 \pm 2 \%$ colony survival. Thus, sufficient drug apparently remained after a single addition of $10 \mu \mathrm{g} / \mathrm{ml}$ to maintain the cytotoxic effects.

These results demonstrate that maximum cell kill is achieved by a continuous drug exposure. How-

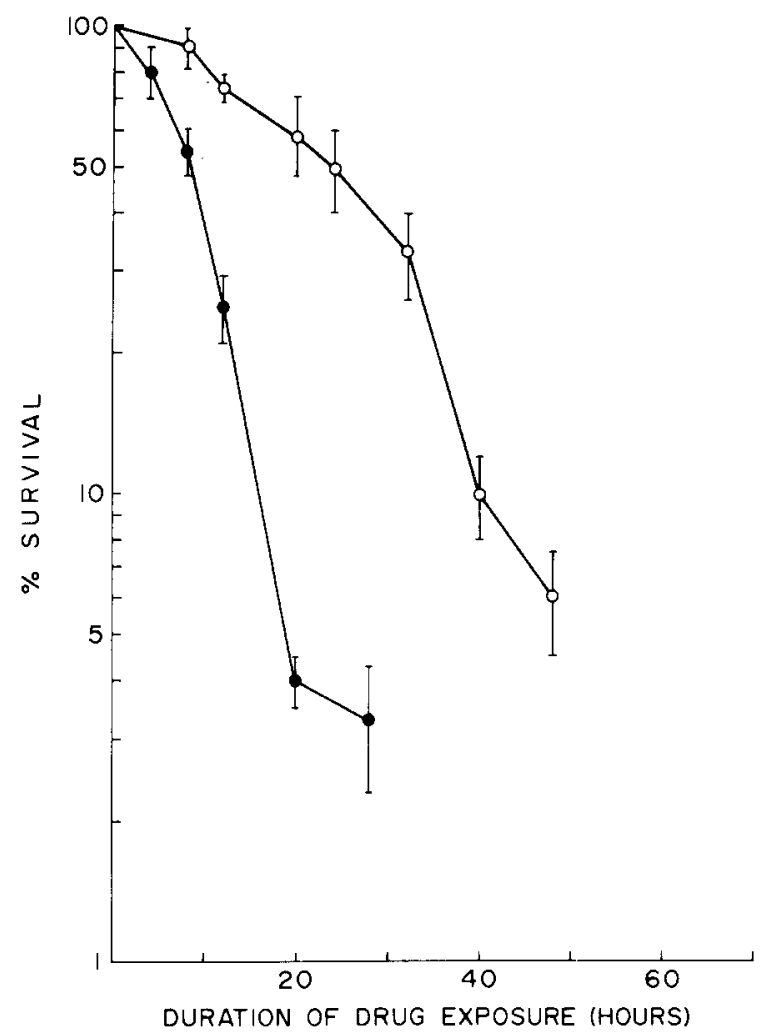

Fig. 3. Comparison of exposure time dependent cytotoxicity of ICRF-187 in $\mathrm{P}_{3} \mathrm{~J}$ and $\mathrm{H} 69 \mathrm{C}$ cells. Cultures were incubated with 20 $\mu \mathrm{g} / \mathrm{ml} \mathrm{ICRF}-187$, and aliquots were removed for soft agar cloning assay at the times indicated. Medium and drug was replaced at $24 \mathrm{~h}$ in the $\mathrm{H} 69 \mathrm{C}$ cultures.

- $\mathrm{P}_{3} \mathrm{~J} ; \mathrm{O}, \mathrm{H} 69 \mathrm{C}$.

ever, with a phase specific agent, a given duration of drug exposure should produce greater cell kill in cells with a short cycle time. The effect of Burkitt cell proliferation rate on ICRF-159 cytotoxicity is shown in Fig. 2. The doubling time of untreated log phase $P_{3} J$ cultures was $13-15 \mathrm{~h}$, and during a 14-h incubation period, the viable cell count of untreated cultures with an initial cell concentration of $0.25 \times 10^{6} \mathrm{cell} / \mathrm{ml}$ increased $107 \%$, compared to a $53 \%$ increase with an initial inoculum of $0.75 \times 10^{6}$ cells $/ \mathrm{ml}$ and $19 \%$ increase with an initial inoculum of $1.5 \times 10^{6}$ cells $/ \mathrm{ml}$. Cultures with an initial concentration of $0.75 \times 10^{6}$ cells $/ \mathrm{ml}$ doubled in cell count after 19-20 h of growth. The cytotoxic effects of a 14-h exposure to $20 \mu \mathrm{g} / \mathrm{ml}$ ICRF-159 decreased as the initial cell inoculum increased, however, when the drug exposure time was extended to $21 \mathrm{~h}$ to encompass the longer doubling time of cultures plated at $0.75 \times 10^{6}$ cells $/ \mathrm{ml}$, the cytotoxicity produced was equal to that observed with the faster 
growing cell population. Since the cell cultures with higher cell counts were at a lower initial $\mathrm{pH}(7.0$ compared to $7.4 \pm 0.1$ ), the effect of culture $\mathrm{pH}$ on the cytotoxicity of ICRF-159 was also investigated. Variation in $\mathrm{pH}$ from 6.9 to 7.9 had no effect on the cytotoxicity of a 12-h exposure to $20 \mu \mathrm{g} / \mathrm{ml}$.

Similar results are seen when two cell lines with different cycle times are compared. Figure 3 shows the effect of a $20 \mu \mathrm{g} / \mathrm{ml}$ exposure on the Burkitt cells, and on a small cell lung cancer line $\mathrm{NCl}-\mathrm{H} 69 \mathrm{C}$ which has a log phase doubling time of $40 \mathrm{~h}$. Twenty $\mu \mathrm{g} / \mathrm{ml}$ produced maximum cytotoxicity in both cell lines. For all durations of exposure there is a preferential killing of the Burkitt line.

In the clinical treatment of solid tumors, sensitive normal tissues, particularly the bone marrow in the case of ICRF-187, would be represented by the more rapidly proliferating cells. An intermittant drug administration which allowed normal tissue recovery would be a potential alternative to continuous drug administration. This alternative was examined in vitro. Burkitt cells were exposed to 20 $\mu \mathrm{g} / \mathrm{ml}$ of ICRF- 187 for $8 \mathrm{~h}$ (a concentration $\times$ time exposure that produced $50 \%$ cell kill), centrifuged, then resuspended in either drug containing medium for an additional $8 \mathrm{~h}$, or drug-free medium. Aliquots of cells incubated in the drug-free medium were removed at 4-h intervals, then re-exposed to ICRF-187 for a second 8-h duration and cytotoxicity assayed. As shown in Fig. 4, an 8-h drug exposure reduced cell survival $50 \%$, and a 16 -h continuous exposure produced $80 \%$ cell kill. As the drug-free incubation was lengthened from 4 to $20 \mathrm{~h}$, the cell population gradually recovered from the initial drug effect. With a 12- to 16-h delay between the two drug exposures, cytotoxicity was equal to a single 8 -h exposure.

The same drug exposure conditions were used with the H69C cell line except that a 20-h exposure time was used. Twenty hours was selected to produce a $50 \%$ cell kill. The results are also displayed in Fig. 4. The time to recovery from the first drug exposure is only slightly delayed compared to the more rapidly proliferating $\mathrm{P}_{3} \mathrm{~J}$ cell line. This suggests that recovery from drug-induced damage is not cycle time dependent, and is not a result of cell growth during the drug-free incubation.

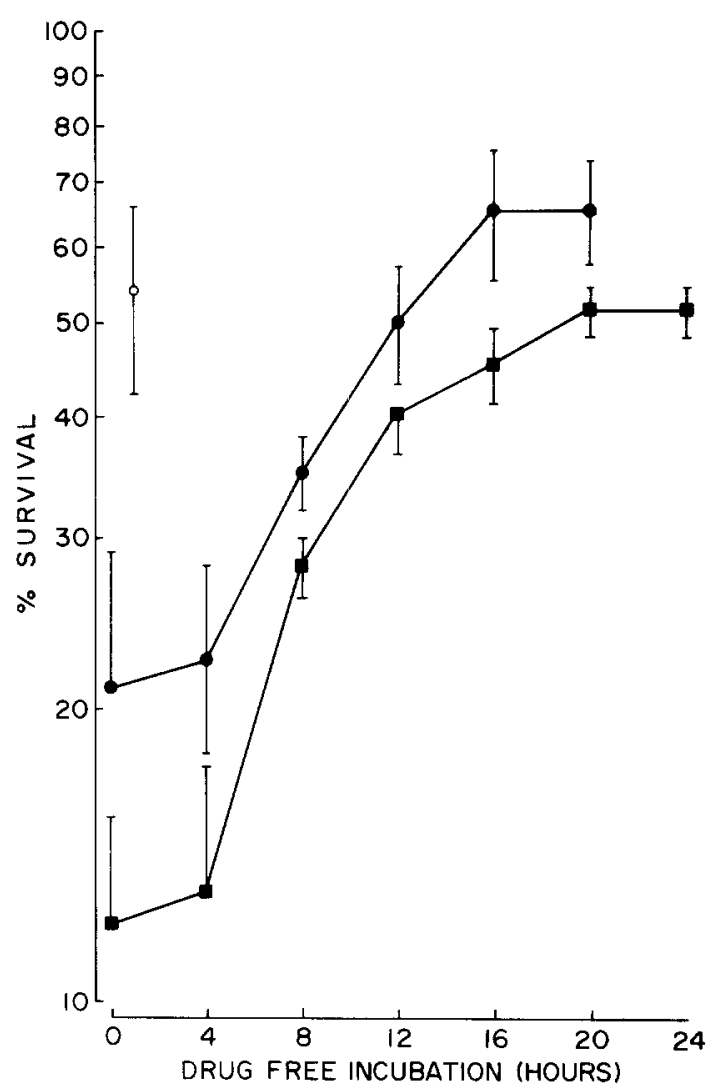

Fig. 4. Time course of recovery from an initial drug exposure. $\mathrm{P}_{3} \mathrm{~J}$ cells were exposed to $20 \mu \mathrm{g} / \mathrm{ml}$ ICRF-187 for $8 \mathrm{~h}$ then placed in drug-free medium for 0 to $24 \mathrm{~h}$ prior to a second 8 -h exposure. H69C cells were exposed to $20 \mu \mathrm{g} / \mathrm{ml}$ for $20 \mathrm{~h}$ during each drug incubation. Cytotoxicity was determined following the second drug exposure.

- $\mathrm{P}_{3} \mathrm{~J} ; \mathbf{H 6 9 C}$; $\bigcirc$, a single drug exposure: $8 \mathrm{~h}$ for $\mathrm{P}_{3} \mathrm{~J}, 20$ h for $\mathrm{H} 69 \mathrm{C}$.

\section{The cytokinetic effect of ICRF-159}

The effect of $20 \mu \mathrm{g} / \mathrm{ml}$ of ICRF-159 on thymidine uptake, mitotic index, and DNA content per cell are shown in Fig. 5. The mitotic index began to fall between 60 and $90 \mathrm{~min}$ of drug exposure; however, thymidine incorporation was not affected until exposure time exceeded $4 \mathrm{~h}$. There was a progressive increase in the DNA content per cell. For comparison, the effects of nitrogen mustard $(0.5 \mu \mathrm{g} / \mathrm{ml})$ and colchicine $(1.0 \mu \mathrm{g} / \mathrm{ml})$ on thymidine incorporation and DNA content per cell are shown in Fig. 6. This was the lowest nitrogen mustard concentration that produced maximum cell kill in this culture system 


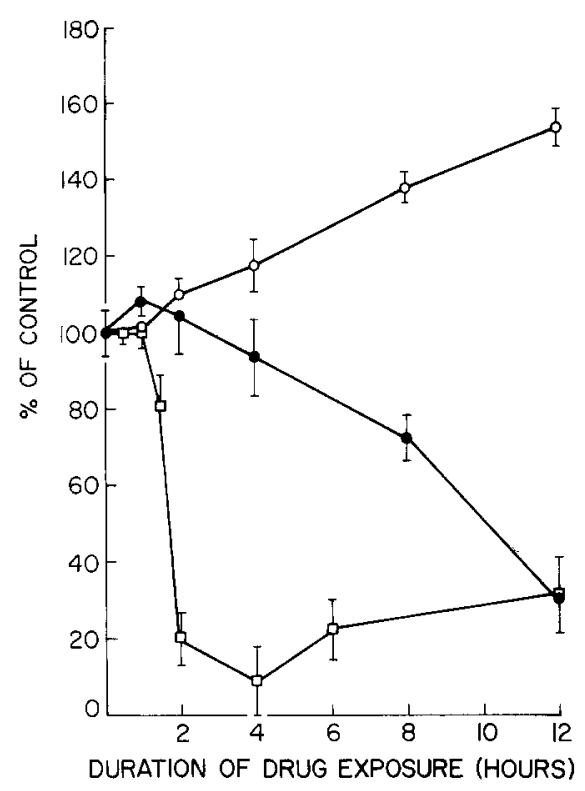

Fig. 5. The cytokinetic effects of ICRF-159 in $\mathrm{P}_{3} \mathrm{~J}$ cells. Simultaneous control and drug treated cells $(20 \mu \mathrm{g} / \mathrm{ml})$ were assayed for mitotic index, thymidine incorporation and cell content of DNA. Percent of control was calculated by dividing the results from the drug treated cultues by the results from concomitant controls. $O$, cell content of DNA; $O$, thymidine incorporation; $\square$, mitotic index.

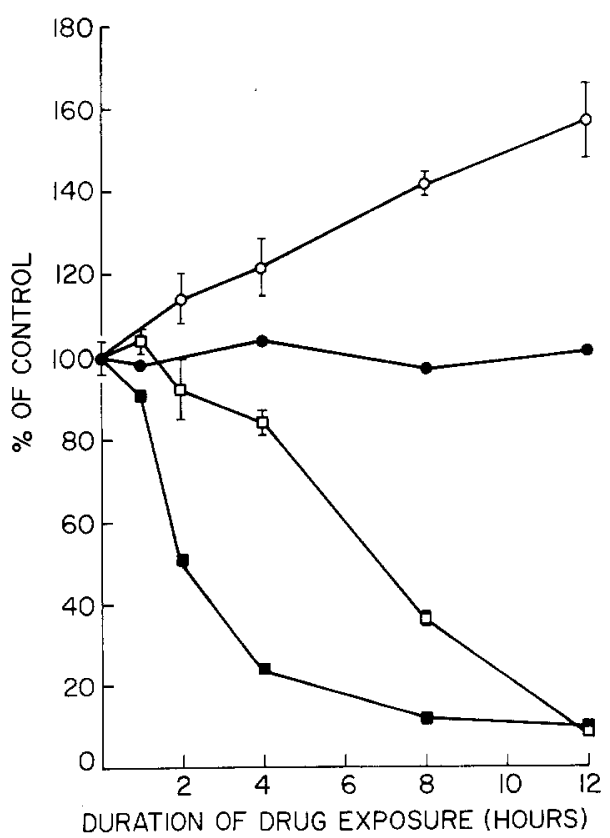

Fig. 6 . The cytokinetic effects of colchicine and nitrogen mustard in $P_{3} \mathrm{~J}$ cells.

O, cell content of DNA, colchicine; cell content of DNA, nitrogen mustard; $\square$, thymidine incorporation, colchicine; $\mathbf{\square}$, thymidine incorporation, nitrogen mustard.

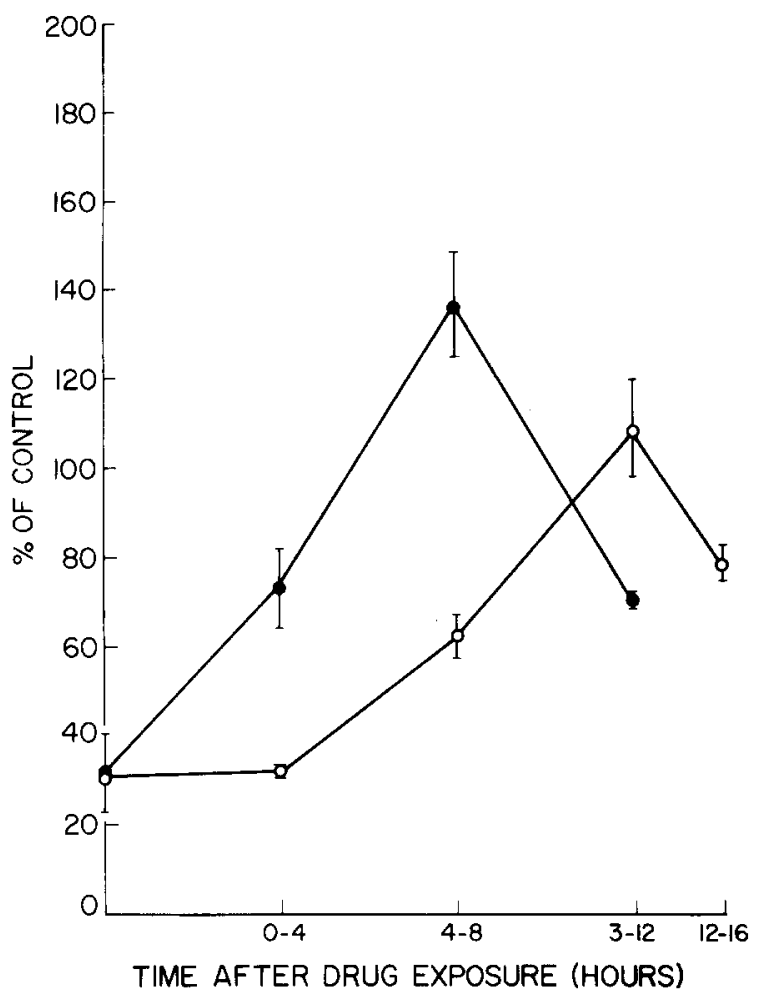

Fig. 7. Changes in mitotic index and thymidine incorporation following exposure to ICRF-159. $\mathrm{P}_{3} \mathrm{~J}$ cells were incubated with $20 \mu \mathrm{g} / \mathrm{ml}$ ICRF-159 for $14 \mathrm{~h}$, then placed in drug-free medium. Aliquots were removed at the times indicated for determination of mitotic index and thymidine incorporation.

$\bigcirc$, thymidine incorporation; $\mathbf{O}$, mitotic index.

(data not shown). The effect of colchicine on thymidine incorporation and cell content of DNA was quite similar to that of ICRF-159. In contrast, nitrogen mustard caused a more rapid drop in thymidine incorporation without increase in DNA content per cell.

To investigate the potential use of ICRF-159 as a synchronizing agent, thymidine incorporation and mitotic index were studied following drug removal (Fig. 7). A peak in mitotic accumulation occurred 4 to $8 \mathrm{~h}$ following removal of ICRF-159. A peak in DNA synthesis was seen 8 to $12 \mathrm{~h}$ following drug removal. These results show that following ICRF-159 exposure, cells move through the subsequent division cycle in a partially synchronized wave.

The effect of a continuous exposure of ICRF-187 at concentrations of $20 \mu \mathrm{g} / \mathrm{ml}, 5 \mu \mathrm{g} / \mathrm{ml}$, and $1 \mu \mathrm{g} / \mathrm{ml}$ 


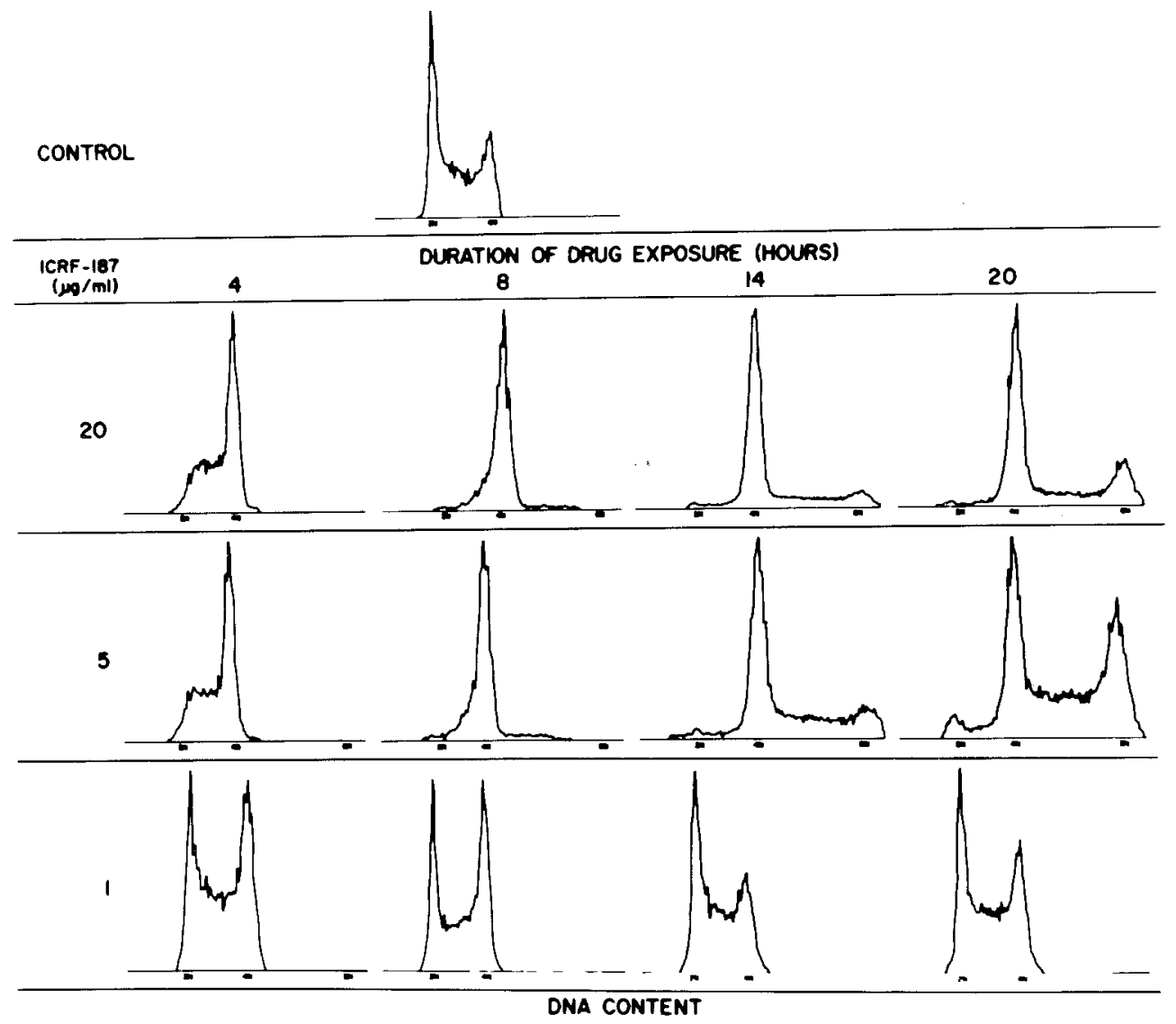

Fig. 8. Changes in cell cycle distribution during a continuous exposure to ICRF-187. $\mathrm{P}_{3} \mathrm{~J}$ cells were incubated with ICRF-187 at the concentrations shown. Aliquots were removed for flow cytometry at the indicated times.

on cell cycle distribution was determined by flow cytometry. As shown in Fig. 8, the two higher drug concentrations rsulted in maximum cell accumulation with a $\mathrm{G}_{2}$ DNA content, whereas $1 \mu \mathrm{g} / \mathrm{ml}$ produced a partial effect. There was no inhibition of cell progression through the $\mathrm{G}_{1} / \mathrm{S}$ boundary or through the DNA synthetic phase. There was, however, an accumulation of cells with an 8N DNA content suggesting that a portion of the cells were capable of subsequent DNA synthesis, but that cytokinesis was prevented. This effect was most pronounced at the $5 \mu \mathrm{g} / \mathrm{ml}$ drug concentration.

To further evaluate the possible use of the ICRF-159 as a synchronizing agent, cells were exposed to $20 \mu \mathrm{g} / \mathrm{ml}$ and $5 \mu \mathrm{g} / \mathrm{ml}$ for $14 \mathrm{~h}$, then resuspended in a drug-free medium. Flow cytometry was performed at sequential time points thereafter. Figure 9 shows the results of this experiment. After removal from the drug-containing medium, the cells proceeded through $G_{1}$ into $S$ in a partially synchronized wave.

To investigate the potential relationship of these in vitro data to clinical therapy, the cytokinetic effects of ICRF-187 on the bone marrow of patients receiving the agent were determined. Figure 10 shows sequential cytofluorographs on a patient who received $1.5 \mathrm{gm} / \mathrm{M}^{2}$ ICRF-187 for three successive days. The baseline marrow shows a standard pretherapy DNA distribution pattern. Twenty-four hours after the first dose $\mathrm{G}_{2} / \mathrm{M}$ accumulation and $\mathrm{S}$ phase depletion is evident. Twenty-four hours following the second dose, $\mathrm{G}_{2} / \mathrm{M}$ accumulation persists with some cells in the $4 \mathrm{~N}-8 \mathrm{~N}$ range. Cells with a $4 \mathrm{~N}-8 \mathrm{~N}$ DNA content are still evident $24 \mathrm{~h}$ after the third dose. Seventy-two hours after the third dose few $S$ or $G_{2} / M$ cells remain in the 


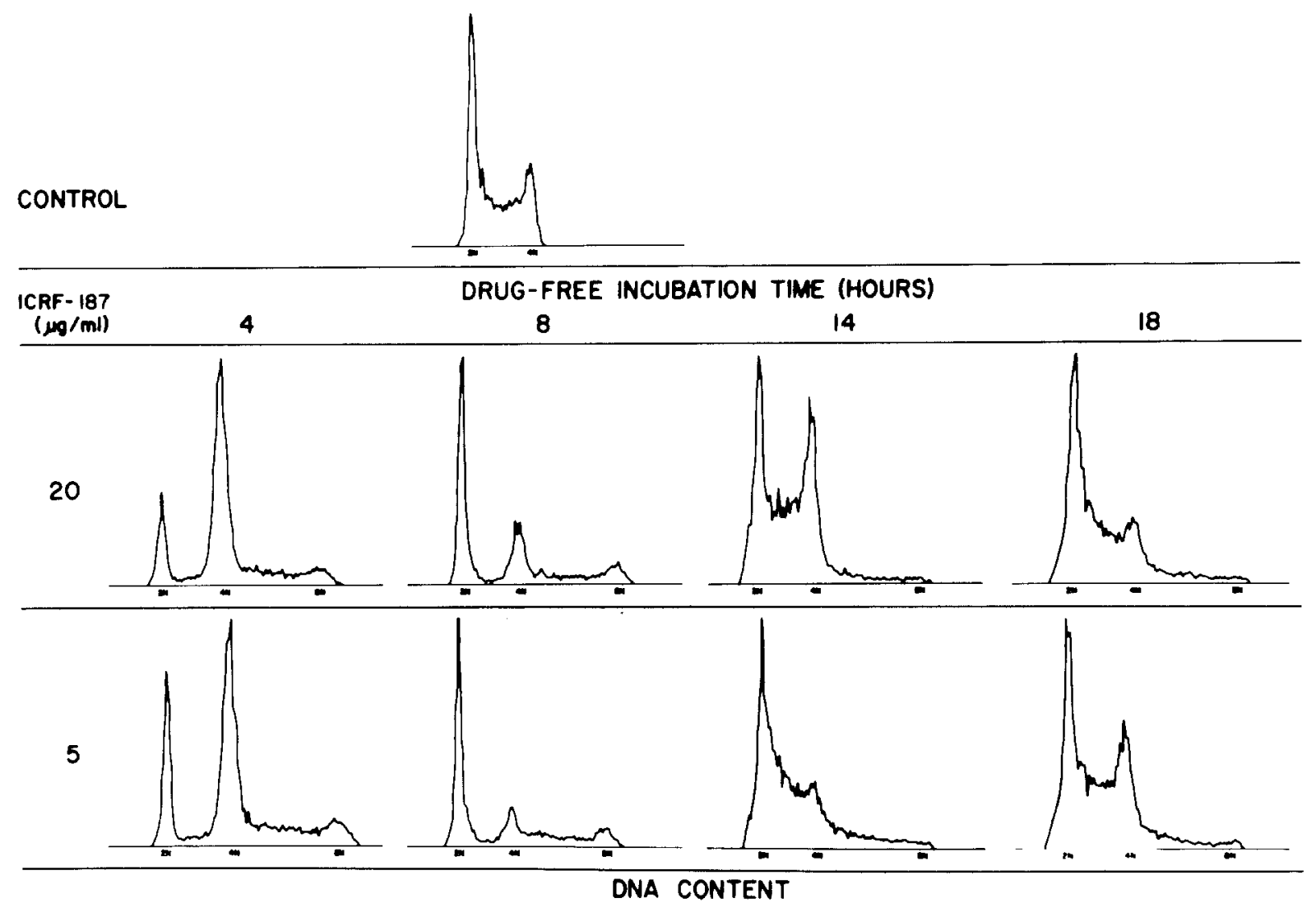

Fig. 9. Changes in cell cycle distribution following exposure to ICRF-187. $\mathrm{P}_{3} \mathrm{~J}$ cells were exposed to 5 or $20 \mu \mathrm{g} / \mathrm{ml} \mathrm{ICRF}-187 \mathrm{for} 14$ $\mathrm{h}$, then placed in drug-free medium. Aliquots were removed for flow cytometry at the times indicated.

\begin{tabular}{|c|c|c|c|c|}
\hline $\begin{array}{l}\text { ICRF }-187 \\
1.5 \mathrm{gm} / \mathrm{M}^{2} / \mathrm{day}\end{array}$ & $\downarrow$ & & & \\
\hline HOURS & 24 & 48 & 72 & 120 \\
\hline
\end{tabular}
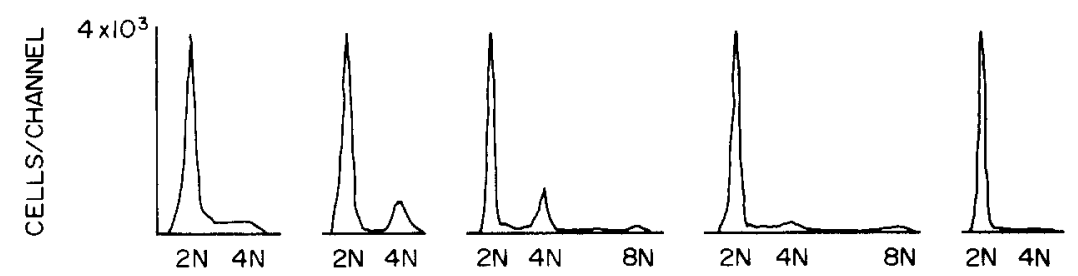

DNA CONTENT

Fig. 10. Effect of ICRF-187 on the bone marrow cell cycle distribution during a daily $\times 3$ treatment course. Bone marrow samples were obtained at the times indicated and processed for flow cytometry. Arrows signify ICRF-187 administration. 

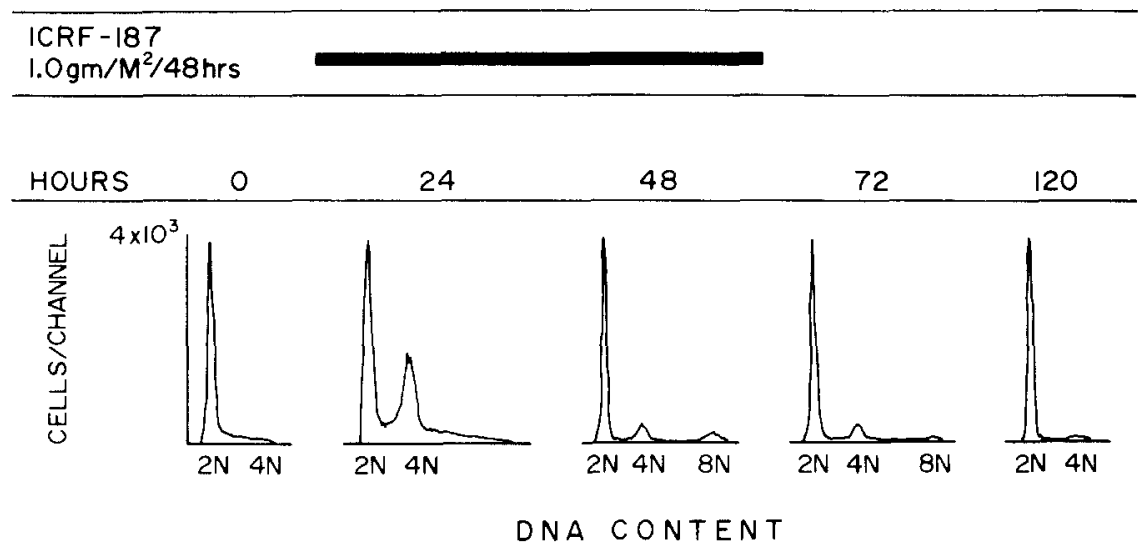

Fig. 11. Effect of $\overline{\mathrm{I}} \overline{\mathrm{C}} \overline{\mathrm{R}} \overline{\mathrm{F}}-187$ on the bone marrow cell cycle distribution during a continuous 48-h treatment course.

\section{ICRF -187}

$1.0 \mathrm{gm} / \mathrm{M}^{2} \times 1$

\section{HOURS}

24

48
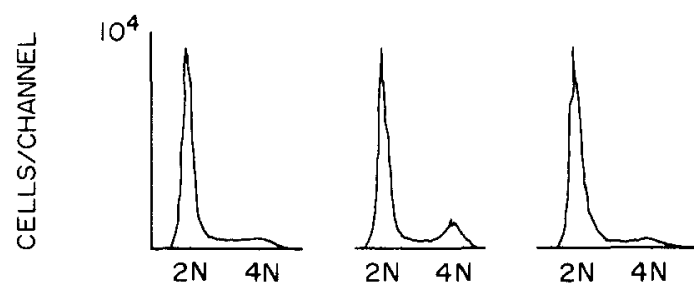

DNA CONTENT

Fig. 12. Changes in bone marrow cell cycle distribution following a single dose of ICRF-187.

marrow. The cytokinetic effects of a 48 -h continuous infusion are shown in Fig. 11. The effects are almost identical to the results seen in the previous patient with $\mathrm{G}_{2} / \mathrm{M}$ accumulation, $4 \mathrm{~N}-8 \mathrm{~N}$ cells and few $\mathrm{S}, \mathrm{G}_{2} / \mathrm{M}$ cells at $120 \mathrm{~h}$. Identical DNA distribution patterns were seen in two patients who received $1.25 \mathrm{gm} / \mathrm{M}^{2}$ ICRF-187 daily for five consecutive days and in one additional patient at both the continuous infusion and daily $\times 3$ dose rates.

To assess the time to recovery from a single dose of ICRF-187, one patient was given an injection of $1.0 \mathrm{gm} / \mathrm{M}^{2}$. As shown in Fig. $12, \mathrm{G}_{2} / \mathrm{M}$ accumulation is evident $24 \mathrm{~h}$ after the dose. Twenty-four hours later the bone marrow has regained a pretherapy DNA distribution.

\section{Discussion}

The cytotoxicity of ICRF-159/187 is clearly related to both drug concentration and duration of exposure. There is minimal inhibitory effect with exposure times less than one-half the cycle time, even with high drug concentrations. Maximum drug effect requires an exposure time at least twice the cell cycle time. Hellman \& Field (9) found similar results using HEp/ 2 cells assayed by the colony forming technique and suggested that the agent must act in a brief portion of the cell cycle. Hallowes et al. (8) found exposure-time dependent variation in ICRF-159 cytotoxicity in three different cell lines. In contrast to our findings, the agent had no effect on cell proliferation during the initial 24-h exposure, but produced progressive cell-kill during a subsequent 48 -h incubation.

Part of the difference in cytotoxicity observed in vitro for various drug concentrations is due to disappearance of the active compound from the medium with a consequent decrease in the duration of exposure. Dawson has shown that the breakdown of ICRF-159 is a pH-dependent hydrolysis (24). The half-life of the drug is approximately 12 $\mathrm{h}$ at $\mathrm{pH} 7.0$. Replacing a $1 \mu \mathrm{g} / \mathrm{ml}$ concentration with fresh drug every $8 \mathrm{~h}$ significantly increased the cytotoxicity. Clear concentration differences remain however, as evidenced by the fact that the addition of fresh drug at a concentration of $1 \mu \mathrm{g} / \mathrm{ml}$ every 8 $\mathrm{h}$ for $24 \mathrm{~h}$ produces less cytotoxicity than an identical $24-\mathrm{h}$ exposure to $10 \mu \mathrm{g} / \mathrm{ml}$. Since the peak 
plasma level achieved in man following a $3 \mathrm{gm} / \mathrm{M}^{2}$ dose is less than $5 \mu \mathrm{g} / \mathrm{ml}$ (25), the duration of drug exposure becomes crucial for attaining an antineoplastic effect. Creaven et al. (26) have shown that the bone marrow suppression that occurs with the clinical use of ICRF-159 is highly schedule-dependent. Part of the schedule dependency, however, may be due to poor oral absorption of high doses with decreased bioavailability (20).

The magnitude of observed drug effect is also greatly dependent upon cell proliferation. As shown by the experiments illustrated in Figs. 2 and 3 , slowly growing cell populations are less sensitive to an equal concentration $x$ time exposure than rapidly growing cells. Equal cytotoxicity can be achieved when exposure time is increased. This proliferation dependence has been demonstrated in other in vivo and in vitro systems $(8,27,28)$. This suggests that the slowly growing tumors encountered clinically could be effectively treated only by a long duration of drug exposure.

Our studies support the contention that ICRF$159 / 187$ is a phase specific agent having a site of action in $\mathrm{G}_{2}$ phase of the cycle $(8-10,27,28)$. Figures 5 and 8 show that ICRF-159 produces a $G_{2}$ arrest in treated cells with a gradual accumulation of cells in this phase of the cell cycle. The mitotic index begins to decline within 60 to $90 \mathrm{~min}$ of drug addition (Fig. 5). Since the duration of $\mathrm{G}_{2}$ in this cell line is $1.5 \mathrm{~h}$, the site of action must be in the $\mathrm{G}_{2}$ phase in order to produce this rapid drop in mitotic index. If the drug produces an immediate effect when added to the cell cultures, then the site of activity would be in early $G_{2}$ (19). However, Dawson has shown that ICRF-159 enters cells slowly by diffusion, and maximum intracellular concentration is not attained for 2 to $3 \mathrm{~h}$ (24). Therefore, the assumption of immediate action may not be warranted, and the drug effect may be occurring later in $\mathrm{G}_{2}$. Others have reported an increase in mitotic index or the percent of prophase cells with ICRF-159 exposure $(10,29)$. We did not observe an increase in mitotic index, and the mitotic cells present were not arrested in prophase.

Following the $G_{2}$ arrest, a fraction of the cells move into DNA synthesis without cell division. This is best demonstrated in the flow cytometric analysis illustrated in Fig. 8. These cells are again arrested in a second $\mathrm{G}_{2}$ peak with an $8 \mathrm{~N}$ DNA content. Other investigators have observed a progressive increase in cell size and an increase in tetraploid cells $(8,30)$. Since the majority of cells remain arrested in the initial $\mathrm{G}_{2}$ block, the subpopulation of cells that proceed into a second synthetic phase are presumably more resistant to the drug effect. Taylor \& Bleehen (31) demonstrated that EMT6 cells resistant to ICRF-159 are polyploid with twice the usual DNA content and chromosome numbers. Hallowes et al. (8) have observed that dead cells as defined by dye exclusion are mononuclear. The demonstration in Fig. 8 of a greater percentage of tetraploid cells with a $5 \mu \mathrm{g} / \mathrm{ml}$ suggests that these cells that achieve tetraploidy are partially drug resistant. In order to kill these cells, the drug must be present throughout the second $\mathrm{G}_{2}$ phase and this explains why a drug exposure of twice the cycle time is necessary for maximum cytotoxicity. In contrast to the stable polyploidy noted by Taylor \& Bleehan, the cultures that recovered from drug treatment in our experiments were made up of cells with normal DNA content. The exposure time used in our experiments, however, may not have been sufficient to produce a stable resistant cell population.

The flow cytometry and thymidine incorporation studies do not show any delay of progression through the $\mathrm{G}_{1} / \mathrm{S}$ boundary or in $\mathrm{S}$ phase transit. DNA synthesis inhibition has been previously reported (11). However, we observe decreased DNA synthesis only after the arrest in $\mathrm{G}_{2}$ progression has depleted the cell pool entering $G_{1}$ and $S$. This is in contrast to an equally cytotoxic concentration of nitrogen mustard which produces a rapid inhibition of thymidine incorporation, and similar to the effect seen with colchicine (Fig. 6). We were unable to detect any increase in thymidine incorporation as reported by Creighton \& Birnie (11) and by Grieder et al. (29). In the latter instance, the thymidine uptake was corrected by the cell count. Since the ICRF-159 produces a rapid decrease in cells passing through mitosis while leaving a $S$ phase undisturbed, an artificial increase in thymidine incorporation would be detected. Hallowes et al. (8) also found no effect on the labelling index during the initial phase of drug exposure. 
There are clear cytokinetic differences between ICRF-159/187 and other compounds which produce $\mathrm{G}_{2} / \mathrm{M}$ arrest in vitro. The alkylating agents, with nitrogen mustard as the prototype, are not phase specific, produce DNA synthesis inhibition at a high concentration, and slow or inhibit transit throughout the cell cycle $(12,32)$. Adriamycin produces a $\mathrm{G}_{2}$ block that correlates with cytotoxicity (13). However, at high drug concentration, transit throughout the cell cycle is inhibited (15), and $\mathrm{S}$ phase cells are most sensitive to the cytotoxic effect (33). Mithramycin and bleomycin produce primarily $\mathrm{G}_{2}$ arrest but inhibit DNA synthesis at high concentrations $(16,34-36)$. Protein synthesis inhibitors such as puromycin delay transit through the $G_{1} / S$ boundary in addition to producing $G_{2}$ arrest (14). Colchicine and the periwinkle analogues vincristine and vinblastine produce metaphase arrest, whereas ICRF-159 exposure results in a fall in mitotic index.

As further contrast between the alkylating agents, antitumor antibiotics and ICRF-159, Dawson was unable to demonstrate covalent binding of ICRF-159 to DNA, or any physical interaction between ICRF-159 and intracellular macromolecules (24). Also, Sharpe et al. could find no visible evidence of chromosome damage following ICRF159 exposure (10).

Any conclusions concerning the mechanism of action of ICRF-159/187 must remain highly speculative. As Tobey has summarized, completion of mitosis requires two discrete periods of protein synthesis just prior to mitosis (37). The mRNA necessary for synthesis of these proteins is transcribed early in $\mathrm{G}_{2}$. ICRF-159/187 could interfere with the early $\mathrm{G}_{2}$ events or could inhibit synthesis of the proteins necessary for initiation of mitosis (38). The cytokinetic effects of ICRF-159/187 may also result in part from inhibition of microfilament synthesis or function. Gosalvey et al. (39) have shown that ICRF-159 will inhibit the capping of surface immunoglobulins, a process dependent upon microfilaments. This inhibition occurs at low drug concentrations and may result from chelation of ferric iron. Cytochalasin B, an inhibitor of microfilament formation, also produces multinucleated cells (31). With ICRF-159/187 additional mechanisms must be active since nuclear division is also inhibited in the majority of cells.

The studies also have implications for clinical therapy with ICRF-159/187. It is clear from Fig. 2 that the drug must be present for at least twice the cell cycle time to produce maximum cell kill. This suggests that a continuous infusion should be more effective than intermittent bolus treatment. However, human tumors in general have considerably longer cell cycle durations than most normal cell populations, and excessive toxicity could result from prolonged infusions. Intermittent drug infusions, with drug-free intervals timed to allow recovery of the normal cells with a short cycle time, may produce a selective cytotoxicity to a slowly growing cell population.

The cytokinetic analysis of the bone marrows of patients receiving ICRF-187 reveal the same effects that were observed in vitro. Proliferating cells are initially blocked in $\mathrm{G}_{2} / \mathrm{M}$. A fraction of the cells continue in cycle without cell division and accumulate with an $8 \mathrm{~N}$ DNA content. A 48-h continuous infusion, and daily 3- or 5-day injections produce marked depletion of the $\mathrm{S}$ and $\mathrm{G}_{2} / \mathrm{M}$ compartments consistent with the subsequent myelosuppression that developed in these patients. The one patient who received a single injection of ICRF-187 had cytokinetic recovery of the bone marrow $48 \mathrm{~h}$ following the dose. Based on these observations, a Phase I study of intermittent ICRF-187 with injections timed to allow bone marrow recovery is indicated.

ICRF-159/187 also has some potential for use as a synchronizing agent in a combination drug regimen. ICRF-159/187 treatment could be followed after an appropriate interval by an $\mathrm{S}$ phase specific agent to take advantage of the partial cell cycle synchrony demonstrated in Fig. 7 and 9. An alternative approach would be to administer the $\mathrm{S}$ phase specific agent at the end of an ICRF-159 infusion timed to produce bone marrow arrest in $\mathrm{G}_{2}$. A tumor cell population, having a longer cell cycle time should not have achieved $S$ phase cell depletion during this short infusion period. These potential clinical applications will require further investigation in animal tumor models. 


\section{Acknowledgments}

This study was supported in part by contract N01CM-07405 from the National Cancer Institute and Public Health Service Grant 5-MO-1-RR-00042.

\section{References}

1. Bakowski MT: ICRF-159, ( \pm ) 1,2-di (3,5-dioxopiperazin-1Y1) propane NSC-129943; Razoxane. Cancer Treat Rev 3:95-107, 1976

2. Bellet RE, Rozencweig M, Von Hoff DD, Penta JS, Masserman TH, Muggia FM: ICRF-159: Current status and clinical prospects. Eur J Cancer 13:1293-1298, 1977

3. Atherton HA, Janes SE, Hellmann K: Inhibition of growth of lung metastases with combined radiation and ICRF-159. (Abstract) Br J Cancer 34:315, 1976

4. Peters LJ: Modification of the radiocurability of a syngeneic murine squamous carcuinoma by its site of growth by electron-affinic drugs, and by ICRF-159. Br J Radiol 49:709715,1976

5. Wampler GL, Speckhart BJ, Regelson W: Phase I clinical study of adriamycin-ICRF-159 combination and other ICRF-159 drug combinations. (Abstract) Proc Am Assoc Cancer Res 15:189, 1974

6. Woodman BJ, Venditti JM, Schepartz SA, Kline I: ICRF159 (1,2-Bis(3,5-Dioxopiperazin-1-YL)-Propane) (NSC129943). Activity against intracerebrally inoculated L1210; therapeutic superiority against IP S1210 in combination with cis-platinum (II) Diamminodichloride (Cis-PT-II: NSC119875). (Abstract) Proc Am Assoc Cancer Res 12:24, 1974

7. Hill HB, Hellman K: Razoxane and methotrexate resistance. Lancet $1: 47,1977$

8. Hallowes RC, West DG, Hellman K: Cumulative cytostatic effect of ICRF-159. Nature 247:487-490, 1974

9. Hellman K, Field EO: Effect of ICRF-159 on the mammalian cell cycle: significance for its use in cancer chemotherapy. J Natl Cancer Inst 44:539-543, 1970

10. Sharpe HBA, Field EO, Hellman K: Mode of action of the cytostatic agent “ICRF-159'”. Nature 226:524-526, 1970

11. Creighto AM, Birnie GD: Biochemical studies on growth-inhibitory Bisdioxopiperazines. I. Effect on DNA, RNA and protein synthesis in mouse-embryo fibro-blasts. Int $\mathrm{J}$ Cancer 5:47-54, 1970

12. DeCosse JJ, Gelfant S: Effects of nitrogen mustard during the cell cycle of the Ehrlich ascites tumor. Exp Cell Res $60: 185-190,1970$

13. Drewinko BJ, Barlogie B: Age-dependent survival and cellcycle progression of cultured cells exposed to chemotherapeutic drugs. Cancer Treat Rep 60:1707-1717, 1976

14. Tobey RA: A simple, rapid technique for determination of the effects of chemotherapeutic agents on mammalian cellcycle traverse. Cancer Res 32:309-316, 1972
15. Barlogie G, Drewinko B, Johnston DA, Freireich EJ: The effect of adriamycin on the cell cycle traverse of a human lymphoid cell line. Cancer Res 36:1975-1979, 1976

16. Barranco SC, Humphrey RM: The effects of bleomycin on survival and cell progression in Chinese hamster cells in vitro. Cancer Res 31:1218-1223, 1971

17. Barranco SC, Luce SK, Ramsdahl MW, Humphrey RM: Bleomycin as a possible synchronizing agent for human tumor cells in vivo. Cancer Res 33:882-887, 1973

18. Costanzi JJ, Loukas D, Gagliano RG, Griggiths C and Barranco $\mathrm{S}$ : Intravenous bleomycin infusion as a potential synchronizing agent in human disseminated malignancies. Cancer 38:1503-1506, 1976

19. Tobey RA: Different drugs arrest cells at a number of distinct stages in $\mathrm{G}_{2}$. Nature 254:245-247, 1975

20. Creaven PJ, Allen LM, Alford DA: The bioavailability in man of ICRF-159, a new oral antineoplastic agent. J Pharm Pharmacol 27:914-918, 1975

21. Repta AJ, Baltezor MJ, Bansal PC; Utilization of an enantiomer as a solution to a pharmaceutical problem: application to solubilization of 1,2-di(4-piperazine-2,6-dione)propane. J Pharm Sci 65:238-242, 1976

22. Burton KA: Study of the conditions and mechanism of the Diphenylamine reaction for the colorimetric estimation of Deoxyribonucleic acid. Biochem J 62:315-323, 1956

23. Krishan A: Rapid flow cytofluorometric analysis of mammalian cell cycle by propidium iodide staining. J Cell Biol 66:188-193, 1975

24. Dawson KM: Studies on the stability and cellular distribution of dioxopiperazines in cultured BHJ-21S cells. Biochem Pharmacol 24:2249-2253, 1975

25. Sadee W, Staroscik J, Finn C, Cohen J: Determination of ( \pm )-1,2-Bis(3,5-dioxopiperazin-yl) Propane plasma levels in rats, rabbits and humans by GLC and mass fragmentography. J Pharm Sci 64:998-1001, 1975

26. Creaven $\mathbf{P H}$, Cohen $\mathrm{MH}$, Hansen $\mathrm{HH}$, Selawry OS, Taylor SG, III: Phase I clinical trial of a single-dose and two weekly schedules of ICRF-159 (NSC-129943). Cancer Chemother Rep 58:393-400, 1974

27. Blackett NM, Adams K: Cell proliferation and the action of cytotoxic agents on haemopoietic tissue. $\mathrm{Br} \mathrm{J}$ Haematol 32:751-758, 1972

28. Taylor IW, Bleehen NM: Changes in sensitivity to radiation and ICRF-159 during the life of monolayer cultures of EMT6 tumor line. Br J Cancer 35:587-594, 1977

29. Grieder A, Maurer R, Stahelin H: Comparative study of early effects of epipodophyllotoxin derivatives and other cytostatic agents on mastocytoma cultures. Cancer Res 37:2998-3005, 1977

30. Stephens TC, Creighton AM: Mechanism of action studies with ICRF-159: effects on the growth and morphology of BHK-21S cells. Br J Cancer 239:99-100, 1974

31. Taylor JW, Bleehen NM: Razoxane-induced polyploidy. Br J Cancer 38:143-147, 1978

32. Wheeler GP, Bowdon BJ, Adamson DJ, Vail MH: Effect of certain nitrogen mustards upon progression of cultured 
HEp-2 cells through the cell cycle. Cancer Res 30:100-111, 1970

33. Kim SH, Kim JH: Lethal effect of adriamycin on the division cycle of HeLa cells. Cancer Res 32:323-325, 1976

34. Sandbert-Wollheim M, Yarbro JW, Kennedy BJ: Effect of mithramycin on HeLa cells. Cancer 21:22-25, 1968

35. Tobey RA: Effects of cytosine arabinoside, daunomycin, mithramycin, azacytidine, adriamycin and camptothecin on mammalian cell cycle traverse. Cancer Res 32:2720-2725, 1972

36. Tobey RA, Crissman HA: Use of flow microfluorometry in detailed analysis of effects of chemical agents on cell cycle progression. Cancer Res 32:2726-2732, 1972

37. Tobey RA, Peterson DF, Anderson EC: Biochemiostry of $\mathrm{G}_{2}$ and mitosis. In: $\mathrm{R}$ Baserga (ed): The Cell Cycle and Cancer. Marcel Dekker, Inc., New York, pp 309-354

38. White K, Creighton AM: Studies of resistance to ICRF-159 in cell line BS/159-1. Br J Cancer 36:421, 1978

39. Gosalvey M, Pezzi L, Vivero C: Inhibition of capping of surface immunoglobulins at femtomolar concentrations of adriamycin, compound ICRF-159 and tetrodotoxin. Biochem Soc Trans 6:659-661, 1978 